\title{
Removal of Transition Metals from Dilute Aqueous Solution by Carboxylic Acid Group containing Absorbent Polymers
}

\section{Z S Liu ${ }^{1 *}$ and G L Rempel ${ }^{2}$}

${ }^{1}$ National Center for Agricultural Utilization Research, ARS/USDA, 1815 N. University Street, Peoria, IL 61604, USA

${ }^{2}$ Department of Chemical Engineering, University of Waterloo Waterloo, Ontario, Canadá

\begin{abstract}
A carboxylic acid group containing resin with cation exchange capacity, $12.67 \mathrm{meq} / \mathrm{g}$, has been used to remove $\mathrm{Cu}^{2+}, \mathrm{Co}^{2+}$ and $\mathrm{Ni}^{2+}$ ions from dilute aqueous solution. The resin had $\mathrm{Cu}^{2+}, \mathrm{Co}^{2+}$ and $\mathrm{Ni}^{2+}$ removal capacity, $216 \mathrm{mg} / \mathrm{g}$, $154 \mathrm{mg} / \mathrm{g}$ and $180 \mathrm{mg} / \mathrm{g}$, respectively. The selectivity of the resin for $\mathrm{Cu}^{2+}$ over $\mathrm{Co}^{2+}$ and $\mathrm{Ni}^{2+}$ was investigated in the presence of $1.0 \mathrm{M}$ or $0.5 \mathrm{M}$ sodium chloride. The resin was found to offer high capacity and selectivity for $\mathrm{Cu}^{2+}$. The sorbed metal ions $\left(\mathrm{Cu}^{2+}, \mathrm{Co}^{2+}\right.$ and $\left.\mathrm{Ni}^{2+}\right)$ were easily stripped with dilute $\mathrm{HCl}$. The sorbed $\mathrm{Co}^{2+}$ and $\mathrm{Ni}^{2+}$ could also be stripped with $1.0 \mathrm{M} \mathrm{NaCl}$.
\end{abstract}

Keywords: Ion-exchange; Selectivity; Sodium chloride; Carboxylic acid group-containing absorbents

\section{Introduction}

During the past two decades, high water absorbing polymers have received considerable interest from both academic and applied research laboratories. These materials show very high water retention capacities, which make them useful for new industrial and biomedical applications [1-3]. The synthetic polyacrylate derived from acrylic acid has emerged as one important high water absorbing polymer, because acrylic acid is cheap and easy to polymerize to products with high molecular weight. The development of high water absorbing polymers prepared by reacting acrylic acid and acrylamide copolymer with formaldehyde (crosslinker) was reported in our previous publication [4]. This cross linked co-polymerization of acrylic acid and acrylamide, referred to as CCPAA absorbent, was found that its absorption capacity depends on the cross linking density. With high cross linking density, e.g. high acrylamide content, it shows relatively low swelling in water. However, these materials are suitable for use as ion-exchange resins, where some swelling is necessary but high swelling ratio must be avoided. It is well known that resin capacity, selectivity and rate behavior for loading and elution are three important functional properties of ionexchange resins for influencing their applications. The equilibrium sorption capacity of a resin is often observed in practice to be much less than the theoretical capacity calculated from resin composition. This is attributed to the inaccessibility of the many sorption sites buried inside the resin matrix. It is expected that this swelling property of the CCPAA resin will benefit its sorption capacity for the metal ions.

Maxim and co-workers [5] recently reported the retention process of the $\mathrm{Cu}^{2+}$ and $\mathrm{Ni}^{2+}$ cations from $\mathrm{CuSO}_{4}$ and $\mathrm{NiSO}_{4}$ aqueous solution by eight acrylic ion exchangers. Liu and coworkers recently reported removal of $\mathrm{Cu}^{2+}, \mathrm{Co}^{2+}$ and $\mathrm{Ni}^{2+}$ from aqueous solution using bio-based carboxylate containing resins [6]. Rivas and coworkers studied the metal retention properties of resins containing amino and carboxylic acid groups (cross linked poly[3-(methacryloylamino)propyl]dimethyl(3sulfopropyl)ammonium hydroxide], P(MAPDSA), and poly[3(methacryloylamino)propyl] dimethyl(3-sulfopropyl)ammonium hydroxide-co-acrylic acid], P(MAPDSA-co-AA). They investigated under competitive and noncompetitive conditions for $\mathrm{Cu}^{2+}, \mathrm{Cd}^{2+}, \mathrm{Hg}^{2+}$, $\mathrm{Zn}^{2+}, \mathrm{Pb}^{2+}$, and $\mathrm{Cr}^{2+}$ ions by batch and column equilibrium procedures. The resin showed that a maximum retention capacity value for $\mathrm{Hg}^{2+}$ at $\mathrm{pH} 2$ was $1.89 \mathrm{meq} / \mathrm{g}$. The resin also showed a high selectivity to $\mathrm{Hg}^{2+}$ ion
[7]. In this work, the water swellable CCPAA resin with 5\% acrylamide has been used for studying sorption characteristics and selectivity for copper over cobalt and nickel. Consequently the distribution behavior of the $\mathrm{Cu}^{2+}, \mathrm{Co}^{2+}$ and $\mathrm{Ni}^{2+}$ in the presence of salt $(\mathrm{NaCl})$ in the solution was calculated presented in this paper. This resin will be explored further for its application in waste water treatment.

\section{Experimental Details}

\section{Preparation of the CCPAA resin}

Details for the synthesis of the CCPAA resin (5\% acrylamide) were given in the literature (4). Typically, a solution of $90 \mathrm{ml}$ distilled water, $0.048 \mathrm{~g}(18 \mathrm{mmol})$ of potassium persulfite and $0.02 \mathrm{~g}(0.09 \mathrm{mmol})$ of potassium metabisulfite were added into a flask fitted with a mechanical stirrer, condenser, thermometer and dropping funnel. At $65^{\circ} \mathrm{C}, 11.40$ $\mathrm{g}(0.16 \mathrm{~mol})$ of acrylic acid and $0.60 \mathrm{~g}(0.008 \mathrm{~mol})$ of acrylamide in $15 \mathrm{ml}$ distilled water were added dropwise in 10 minutes, followed by adjusting $\mathrm{pH}$ to about 4.5 with sodium hydroxide solution. The mixture was heated to $75^{\circ} \mathrm{C}$. The polymerization began in about 10 minutes. The system was maintained for $2 \mathrm{hrs}$ at $70^{\circ} \mathrm{C} .3 .7 \mathrm{ml}$ formaldehyde solution was then added at $45^{\circ} \mathrm{C}$ and maintained for $1 \mathrm{hr}$. The system was heated to $70^{\circ} \mathrm{C}$ and maintained for $3 \mathrm{hrs}$. The product was dewatered with ethanol and dried to solid product at $80^{\circ} \mathrm{C}$ overnight. The resin was ground to pass 60 mesh sieves. The cation exchange capacity of the CCPAA resin was measured according to the method described by Kunin [8] and was found to be $12.67 \mathrm{meq} / \mathrm{g}$.

\section{Reagents}

Copper sulphate, $\mathrm{CuSO}_{4} \cdot 5 \mathrm{H}_{2} \mathrm{O}$ and cobalt sulphate, $\mathrm{CoSO}_{4} \cdot 7 \mathrm{H}_{2} \mathrm{O}$ were obtained from J. T. Baker, USA. They were Baker analyzed reagents. Nickel sulphate, $\mathrm{NiSO}_{4} \cdot 6 \mathrm{H}_{2} \mathrm{O}$ was obtained from Fisher

${ }^{*}$ Corresponding author: Z. S. Liu, National Center for Agricultural Utilization Research, ARS/USDA, 1815 N. University Street, Peoria, IL 61604, USA, Tel: 1 309-681-6104; Fax: 1 309-681-6524; E-mail: kevin.liu@ars.usda.gov

Received February 20, 2011; Accepted March 29, 2011; Published April 22, 2011

Citation: Liu ZS, Rempel GL (2011) Removal of Transition Metals from Dilute Aqueous Solution by Carboxylic Acid Group containing Absorbent Polymers. Hydrol Current Res 2:107. doi:10.4172/2157-7587.1000107

Copyright: (c) 2011 Liu ZS, et al. This is an open-access article distributed unde the terms of the Creative Commons Attribution License, which permits unrestricted use, distribution, and reproduction in any medium, provided the original author and source are credited. 
Scientific Company, USA. It was a Fisher certified reagent. Copper, cobalt and nickel atomic absorption standard solutions were obtained from Aldrich, USA. They were $1,000 \mathrm{ppm}$ in $1 \% \mathrm{HNO}_{3}$.

\section{Analysis}

Metal ions in aqueous solution were measured with ARL (applied Research Laboratories) SpectraSpan-7 DCP emission spectrometer.

\section{Sorption experiments}

In all equilibrium studies, measured amounts of sorbent was vigorously shaken with definite volumes of solution of known metal concentration for $20 \mathrm{hrs}$ in tightly stoppered glass bottles at ambient temperature, using a gyratory shaker with $2 \mathrm{~cm}$ eccentricity at $300 \mathrm{rpm}$. The residual metal concentrations in solution were measured. A range of concentrations ( $1 \mathrm{mM} / \mathrm{L}$ to $10 \mathrm{mM} / \mathrm{L})$ was employed for each of the metal species, $\mathrm{Cu}^{2+}, \mathrm{Co}^{2+}$ and $\mathrm{Ni}^{2+}$ chosen for the study. The $\mathrm{pH}$ values of the solution for $\mathrm{CuSO}_{4}, \mathrm{CoSO}_{4}$ and $\mathrm{NiSO}_{4}$ are 5.0-5.4, 5.1-5.3 and 5.7-6.0, respectively. The sorption was also measured as a function of time under vigorous agitation.

The sorption capacity of the CCPAA resin for $\mathrm{Cu}^{2+}, \mathrm{Co}^{2+}$ and $\mathrm{Ni}^{2+}$ was measured by agitating the resin $(0.50 \mathrm{~g})$ in excess of $0.1 \mathrm{M} \mathrm{CuSO}_{4}$, $0.1 \mathrm{M} \mathrm{CoSO}_{4}$ and $0.1 \mathrm{M} \mathrm{NiSO}_{4}$ solution $(50 \mathrm{~mL})$, respectively, for 20 hrs. The results showed that the sorption capacities of CCPAA resin for $\mathrm{Cu}^{2+}, \mathrm{Co}^{2+}$ and $\mathrm{Ni}^{2+}$ were $216 \mathrm{mg} / \mathrm{g}, 154 \mathrm{mg} / \mathrm{g}$ and $180 \mathrm{mg} / \mathrm{g}$, respectively. The sorption capacity of the CCPAA resin showed higher than that of ion-exchange resin prepared by conversion of soybean oil, which are $192 \mathrm{mg} / \mathrm{g}, 78 \mathrm{mg} / \mathrm{g}$ and $96 \mathrm{mg} / \mathrm{g}$, respectively [6]. The accessibility of functional groups on the resin may be a key factor because of swell ability of the resin.

\section{Selectivity experiments}

The selectivity of the sorption for $\mathrm{Cu}^{2+}$ over $\mathrm{Co}^{2+}$ and $\mathrm{Ni}^{2+}$ was studied. The measured amounts of the sorbent were vigorously shaken with definite volumes of solution of known metal concentration (combinations of 2 metals at a time) in the presence of varying concentrations of sodium chloride for $20 \mathrm{hrs}$ at ambient temperature. The residual metal concentration in solution was determined. A range of concentrations ( $1 \mathrm{mM} / \mathrm{L}$ to $10 \mathrm{mM} / \mathrm{L}$ ) was employed for each pair of metal species.

\section{pH Runs}

Sulphuric acid was used to acidify the solution. The $\mathrm{pH}$ range employed for the $\mathrm{pH}$ profiles was from $1.85-6.84$. Once $20 \mathrm{~mL}$ of the metal solution $(4 \mathrm{mM} / \mathrm{L})$ was added, the bottles were placed evenly on a platform shaker at $300 \mathrm{rpm}$ for $20 \mathrm{hrs}$ at ambient temperature. The residual metal concentration in solution was measured.

\section{Stripping behavior}

In the stripping experiments, $0.04 \mathrm{~g}$ of the CCPAA resin, on which sorbed $8.64 \mathrm{mg} \mathrm{Cu}^{2+}$, or $6.16 \mathrm{mg} \mathrm{Co}{ }^{2+}$, or $7.2 \mathrm{mg} \mathrm{Ni}^{2+}$, was used. The bottles were placed evenly on a platform shaker at $300 \mathrm{rpm}$ at ambient temperature. The time was started when the acid solution $(\mathrm{HCl})$ first hit the resin particles. The bottles were removed at $15 \mathrm{~min}, 30 \mathrm{~min}, 1 \mathrm{hr}, 2$ hrs, $3 \mathrm{hrs}$ and $4 \mathrm{hrs}$ intervals. The metal concentrations in the solutions were measured. Sorbed $\mathrm{Co}^{2+}$ and $\mathrm{Ni}^{2+}$ ions were also stripped by using 1.0 $\mathrm{M} \mathrm{NaCl}$ solution. The bottles were removed at $4 \mathrm{hrs}, 12 \mathrm{hrs}, 24 \mathrm{hrs}$ and 30 hrs intervals.

\section{Results and Discussion}

\section{Sorption isotherm}

The sorption isotherm was studied using metal concentrations between $1 \mathrm{mM} / \mathrm{L}$ to $10 \mathrm{mM} / \mathrm{L}$ at $\mathrm{pH} 5.0-6.0$ and ambient temperature. The equilibrium data for the sorption of $\mathrm{Cu}^{2+}, \mathrm{Co}^{2+}$ and $\mathrm{Ni}^{2+}$ from aqueous solutions by the CCPAA resin was plotted against equilibrium solution in Figure 1. The results showed that the CCPAA resin could take up significant quantities of $\mathrm{Cu}^{2+}, \mathrm{Co}^{2+}$ and $\mathrm{Ni}^{2+}$. At lower metal concentrations $(<6 \mathrm{mM} / \mathrm{L})$, the sorption capacity of the CCPAA resin for $\mathrm{Cu}^{2+}, \mathrm{Co}^{2+}$ and $\mathrm{Ni}^{2+}$ did not change significantly. However, at higher concentrations $(>8 \mathrm{mM} / \mathrm{L})$, the metal ions were adsorbed in roughly the order $\mathrm{Cu}^{2+}>\mathrm{Ni}^{2+}>\mathrm{Co}^{2+}$.

The equilibrium sorption data of copper in Figure 1 fitted well to the Freundlich isotherm, whereas they were fitted poorly by a Langmuir isotherm. The equilibrium sorption data of cobalt and nickel fitted well both to the Freundlich isotherm and to the Langmuir isotherm. Thus, for the sorption of $\mathrm{Cu}^{2+}, \mathrm{Co}^{2+}$ and $\mathrm{Ni}^{2+}$, the Freundlich isotherm might be written as:

$$
X^{\star}=m C^{\star n}
$$

where $X^{*}$ and $C^{*}$ are the equilibrium sorption and equilibrium concentration of sorbate, respectively, and $m$ ( $\mathrm{mmol} / \mathrm{g}$ dry resin) and $n$ are adjustable parameters. To solve for the isotherm constants, the function may be linearized by taking the natural logarithm of each side (eq .2).

$$
\ln X^{\star}=\ln m+n \ln C^{*}
$$

Values of $m$ and $n$ were determined by least-squares fit of the sorption data in Figure 1 and were presented in Table 1. For the sorption of $\mathrm{Co}^{2+}$ and $\mathrm{Ni}^{2+}$, the Langmuir isotherm may be written as:

$$
C_{A}^{*} / X^{*}=1 / K_{b} A_{s}+C_{A}^{*} / A_{s}
$$

where $X^{*}$ and $C_{A}{ }^{*}$ are the equilibrium sorption ( $\mathrm{mmol} / \mathrm{g}$ dry resin) and equilibrium concentration $(\mathrm{mM} / \mathrm{L})$ of metal ion in solution, respectively. The values of the saturation constant, $A_{S}$ ( $\mathrm{mmol} / \mathrm{g}$ dry resin), and the binding constant, $K_{b}\left(\mathrm{mM}^{-1}\right)$ were determined by leastsquares fit and were presented in Table 1.

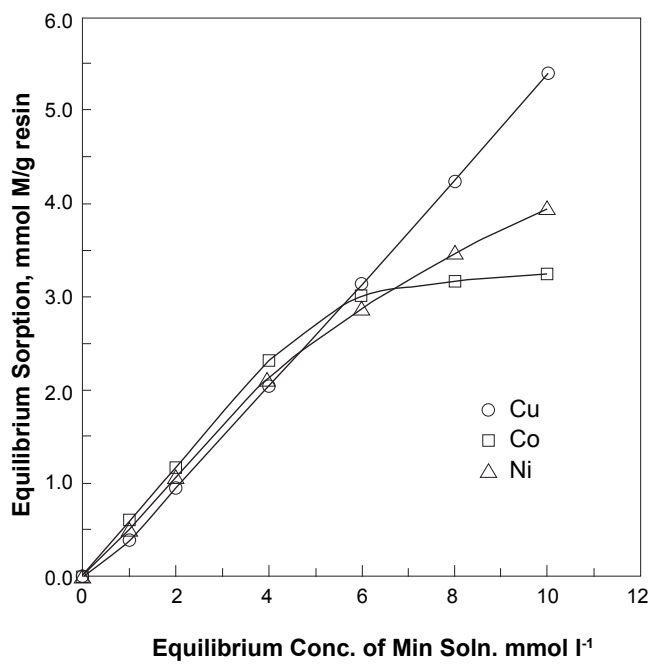

Figure 1: Equilibrium sorption of $\mathrm{Cu}^{2+}, \mathrm{Co}^{2+}$ and $\mathrm{Ni}^{2+}$ from sulphate solutions on CCPAA resin (resin loading: $1.5 \mathrm{~g} / \mathrm{L}$ ). 
Citation: Liu ZS, Rempel GL (2011) Removal of Transition Metals from Dilute Aqueous Solution by Carboxylic Acid Group containing Absorbent Polymers. Hydrol Current Res 2:107. doi:10.4172/2157-7587.1000107

\section{Effect of salt}

Experiments were conducted to determine the effect of high background concentration of sodium chloride. It was found that neither of $\mathrm{NaCl}$ concentrations of $0.5 \mathrm{M}$ and $1.0 \mathrm{M}$ has any significant effect on the $\mathrm{Cu}^{2+}$ sorption capacity of the CCPAA resin as seen in Figure 2. However the $\mathrm{Co}^{2+}$ and $\mathrm{Ni}^{2+}$ sorptions capacity on the CCPAA resin decreased drastically over the whole range of sorbate concentrations employed as seen in Figure 3 and Figure 4. This may lead to a method of separating $\mathrm{Cu}^{2+}$ from $\mathrm{Co}^{2+}$ and $\mathrm{Ni}^{2+}$, since commercial cation-exchange

\begin{tabular}{|l|l|l|l|l|l|l|}
\hline Sorbate & \multicolumn{3}{|l|}{ Freundlich isotherm eq. (2) } & \multicolumn{3}{l|}{ Langmuir isotherm, eq. (3) } \\
\hline & $\begin{array}{l}\mathrm{m} \\
\text { (mmol/g dry resin) }\end{array}$ & $\mathrm{n}$ & $\begin{array}{l}\text { corr. } \\
\text { coeff. }\end{array}$ & $\begin{array}{l}\text { As (mmol/g } \\
\text { dry resin) }\end{array}$ & $\begin{array}{l}\mathrm{K}_{\mathrm{b}} \\
\left(\mathrm{I} \mathrm{mmol} \mathrm{mm}^{-1}\right)\end{array}$ & $\begin{array}{l}\text { corr. } \\
\text { coeff. }\end{array}$ \\
\hline $\mathrm{CuSO}_{4}$ & 0.4041 & 1.139 & 0.998 & & & \\
\hline $\mathrm{CoSO}_{4}$ & 0.5455 & 0.900 & 0.989 & 47.62 & 0.011 & 0.996 \\
\hline $\mathrm{NiSO}_{4}$ & 0.6703 & 0.764 & 0.959 & 10 & 0.065 & 0.995 \\
\hline
\end{tabular}

Table 1: Parameters of Freundlich and Langmuir isotherm for sorption on the CCPAA resin.

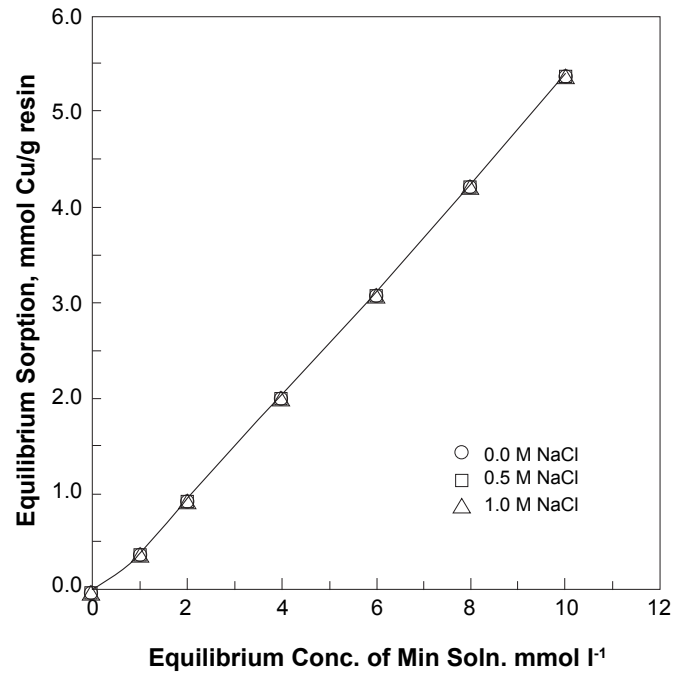

Figure 2: Equilibrium sorption of $\mathrm{Cu}^{2+}$ from $\mathrm{CuSO}_{4}$ solution with $0.5 \mathrm{M} \mathrm{NaCl}$ and $1.0 \mathrm{M} \mathrm{NaCl}$ on CCPAA resin (resin loading: $1.5 \mathrm{~g} / \mathrm{L}$ ).

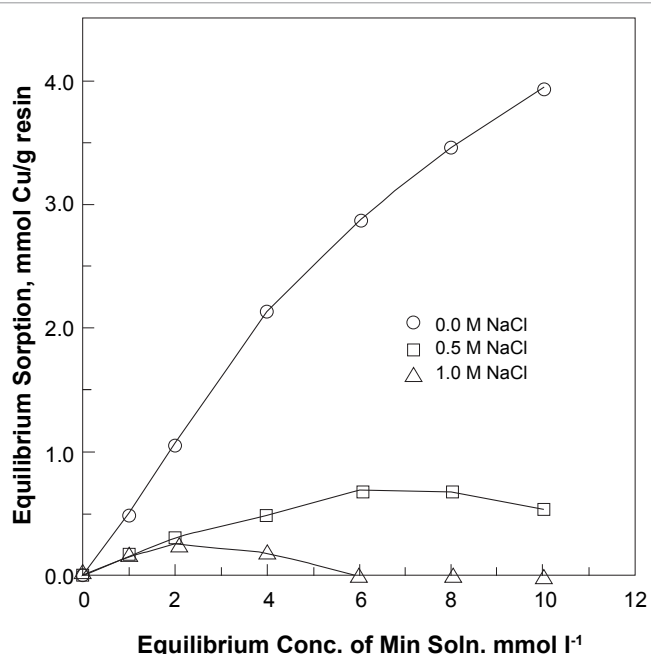

Figure 3: Equilibrium sorption of $\mathrm{Co}^{2+}$ from $\mathrm{CoSO}$ solution with $0.5 \mathrm{M} \mathrm{NaCl}$ and $1.0 \mathrm{M} \mathrm{NaCl}$ on CCPPAA resin (resin loading: $1.5 \mathrm{~g} / \mathrm{L}$ ).

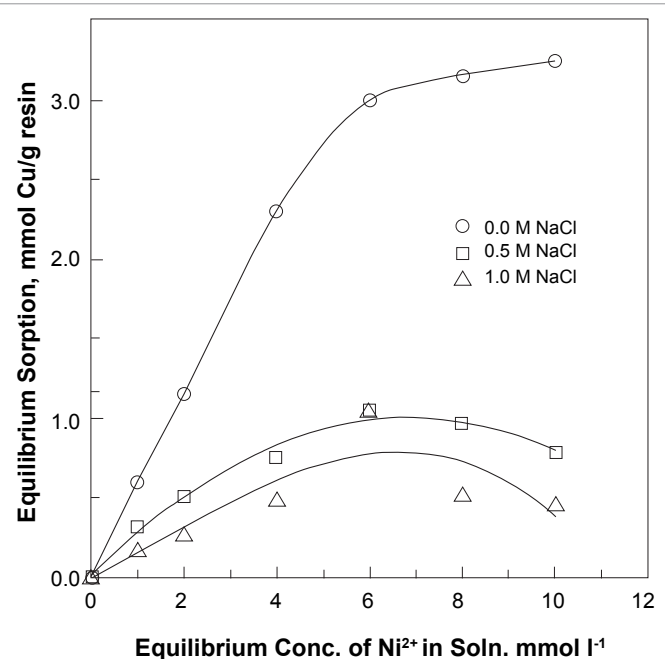

Figure 4: Equilibrium sorption of $\mathrm{Ni}^{2+}$ from $\mathrm{NiSO}_{4}$ solution with $0.5 \mathrm{M} \mathrm{NaCl}$ and $1.0 \mathrm{M} \mathrm{NaCl}$ on CCPAA resin (resin loading: $1.5 \mathrm{~g} / \mathrm{L}$ ).

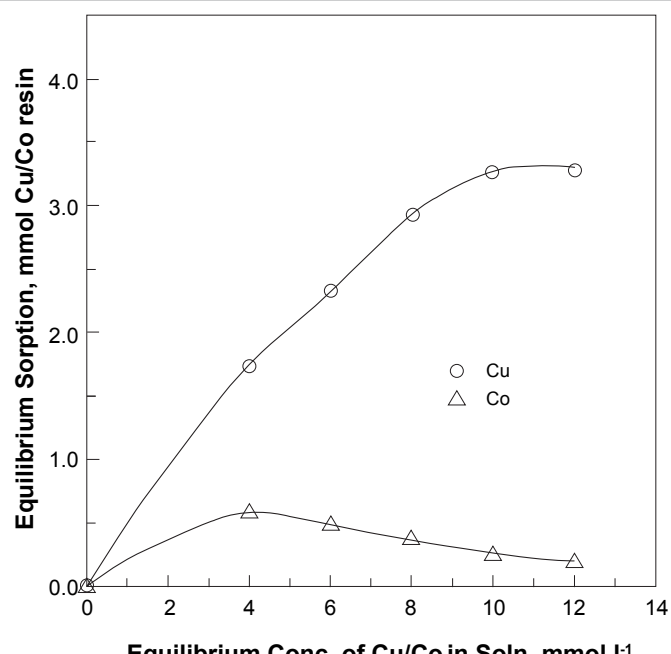

Figure 5: Equilibrium sorption of $\mathrm{Cu}^{2+} / \mathrm{Co}^{2+}$ from sulphate solution with $1.0 \mathrm{M}$ $\mathrm{NaCl}$ on CCPAA resin (resin loading: $1.5 \mathrm{~g} / \mathrm{L}$ ).

resins containing sulfonic or carboxylic functional groups have limited potential for removal and recovery of heavy metals from process solutions and waste streams because of their low selectivity.

\section{Selectivity for copper (II)}

In hydrometallurgy, considerable interest exists in the separation of $\mathrm{Cu}^{2+}$ from $\mathrm{Co}^{2+}$ and $\mathrm{Ni}^{2+}$, therefore, the selectivity of the CCPAA resin for $\mathrm{Cu}^{2+}$ over $\mathrm{Co}^{2+}$ or $\mathrm{Ni}^{2+}$ with presence of $1.0 \mathrm{M} \mathrm{NaCl}$ in the solution was investigated. Figure 5 and Figure 6 showed the results of two mixed solutions, in which each metal ion concentration was varied from 4 $\mathrm{mM} / \mathrm{L}$ to $12 \mathrm{mM} / \mathrm{L}$. It can be seen from Figure 5 and Figure 6 that the CCPAA resin is able to absorb about 10 times more $\mathrm{Cu}^{2+}$ than $\mathrm{Co}^{2+}$ and $\mathrm{Ni}^{2+}$ at higher metal concentrations $(>8 \mathrm{mM} / \mathrm{L})$. However, the sorption capacity differences between $\mathrm{Cu}^{2+}, \mathrm{Co}^{2+}$ and $\mathrm{Ni}^{2+}$ were also rather large at lower metal concentrations $(<6 \mathrm{mM} / \mathrm{L})$. It may be predicted that the separation of $\mathrm{Cu}^{2+}$ from $\mathrm{Co}^{2+}$ and $\mathrm{Ni}^{2+}$ is possible with the CCPAA resin in the presence of salt in solution. 
Citation: Liu ZS, Rempel GL (2011) Removal of Transition Metals from Dilute Aqueous Solution by Carboxylic Acid Group containing Absorbent Polymers. Hydrol Current Res 2:107. doi:10.4172/2157-7587.1000107

Page 4 of 6

\section{Fraction of copper, nickel and cobalt among several complex species}

It is well known that in the presence of $\mathrm{Cl}^{-}$in solution, the four coordinate M (II) complexes are formed, which reported in literature [6,9]. Taking copper as an example, the stepwise formation constant $\mathrm{K}_{\mathrm{i}}$, which stands for $\mathrm{K}_{1}$ to $\mathrm{K}_{4}$, associated with each of four equilibria, may be obtained from the book of "Stability Constants," edited by Silln et al. [10] and literature [11], it was found that the values of stepwise formation constants $\mathrm{K}_{\mathrm{i}}$ are $2.80,1.60,0.49$ and 0.73 , respectively. Considering the overall formation, the equation may be written as follows:

$$
\begin{aligned}
& \mathrm{Cu}^{2+}+\mathrm{Cl}^{-} \stackrel{\beta_{1}}{\rightleftharpoons} \mathrm{CuCl}^{+} \\
& \mathrm{Cu}^{2+}+2 \mathrm{Cl}^{-} \stackrel{\beta_{2}}{\rightleftharpoons} \mathrm{CuCl} \\
& \mathrm{Cu}^{2+}+3 \mathrm{Cl}^{-} \stackrel{\beta_{3}}{\rightleftharpoons} \mathrm{CuCl}_{3}^{-} \\
& \mathrm{Cu}^{2+}+4 \mathrm{Cl}^{-} \stackrel{\beta_{4}}{\rightleftharpoons} \mathrm{CuCl}_{4}^{2-}
\end{aligned}
$$

From equation (4), the mass balance equation for each species of complex can be obtained as equation 5 .

$$
\begin{aligned}
& \beta_{1}=\frac{\left[\mathrm{CuCl}^{+}\right]}{\left[\mathrm{Cu}^{2+}\right]\left[\mathrm{Cl}^{-}\right]} \\
& \beta_{2}=\frac{\left[\mathrm{CuCl}_{2}\right]}{\left[\mathrm{Cu}^{2+}\right]\left[\mathrm{Cl}^{-}\right]^{2}} \\
& \beta_{3}=\frac{\left[\mathrm{CuCl}_{3}^{-}\right]}{\left[\mathrm{Cu}^{2+}\right]\left[\mathrm{Cl}^{-}\right]^{3}} \\
& \beta_{4}=\frac{\left[\mathrm{CuCl}_{4}^{2-}\right]}{\left[\mathrm{Cu}^{2+}\right]\left[\mathrm{Cl}^{-}\right]^{4}}
\end{aligned}
$$

The formation constants, $\beta_{1}, \beta_{2}, \beta_{3}$, and $\beta_{4}$, are found to have relationships to $\mathrm{K}$ constants as follows:

$$
\beta_{1}=\mathrm{K}_{1}, \beta_{2}=\mathrm{K}_{1} \mathrm{~K}_{2}, \beta_{3}=\mathrm{K}_{1} \mathrm{~K}_{2} \mathrm{~K}_{3} \text {, and } \beta_{4}=\mathrm{K}_{1} \mathrm{~K}_{2} \mathrm{~K}_{3} \mathrm{~K}_{4} \text {. }
$$

By substituting the $\mathrm{K}$ values (already known from the literature),

\begin{tabular}{|c|c|c|c|c|c|c|c|c|}
\hline \multirow{2}{*}{ Fraction } & \multicolumn{2}{|c|}{$\left[\mathrm{Cl}^{-}\right] 1.0 \mathrm{M}$} & \multicolumn{2}{|c|}{$\left[\mathrm{Cl}^{-}\right] 0.5 \mathrm{M}$} & \multicolumn{2}{|c|}{$\left[\mathrm{Cl}^{-}\right] 1.0 \mathrm{M}$} & \multicolumn{2}{|c|}{$\left[\mathrm{Cl}^{-}\right] 0.5 \mathrm{M}$} \\
\hline & copper & nickel & copper & nickel & copper & cobalt & copper & cobalt \\
\hline$\alpha_{0}$ & $\begin{array}{l}1.92 x \\
10^{-6}\end{array}$ & $\begin{array}{l}1.92 x \\
10^{-6}\end{array}$ & $\begin{array}{l}2.36 \times \\
10^{-5}\end{array}$ & $\begin{array}{l}2.36 \times \\
10^{-5}\end{array}$ & $\begin{array}{l}1.92 \times \\
10^{-6}\end{array}$ & $\begin{array}{l}1.92 \times \\
10^{-6}\end{array}$ & $\begin{array}{l}2.36 \times \\
10^{-5}\end{array}$ & $\begin{array}{l}2.36 \times \\
10^{-5}\end{array}$ \\
\hline$\alpha_{1}$ & $\begin{array}{l}1.21 x \\
10^{-3}\end{array}$ & $\begin{array}{l}1.42 x \\
10^{-6}\end{array}$ & $\begin{array}{l}7.45 \times \\
10^{-3}\end{array}$ & $\begin{array}{l}8.70 x \\
10^{-6}\end{array}$ & $\begin{array}{l}1.21 x \\
10^{-3}\end{array}$ & $\begin{array}{l}1.32 x \\
10^{-6}\end{array}$ & $\begin{array}{l}7.45 x \\
10^{-3}\end{array}$ & $\begin{array}{l}8.10 x \\
10^{-6}\end{array}$ \\
\hline$\alpha_{2}$ & $\begin{array}{l}4.80 \times \\
10^{-6}\end{array}$ & $\begin{array}{l}1.50 \times \\
10^{-6}\end{array}$ & $\begin{array}{l}1.48 x \\
10^{-1}\end{array}$ & $\begin{array}{l}4.60 \times \\
10^{-5}\end{array}$ & $\begin{array}{l}4.80 \times \\
10^{-2}\end{array}$ & $\begin{array}{l}9.80 \times \\
10^{-7}\end{array}$ & $\begin{array}{l}1.48 \times \\
10^{-1}\end{array}$ & $\begin{array}{l}3.00 x \\
10^{-6}\end{array}$ \\
\hline$\alpha_{3}$ & $\begin{array}{l}1.49 x \\
10^{-1}\end{array}$ & $\begin{array}{l}2.27 \times \\
10^{-6}\end{array}$ & 0.23 & $\begin{array}{l}3.50 \times \\
10^{-6}\end{array}$ & $\begin{array}{l}1.49 x \\
10^{-1}\end{array}$ & N/A & 0.23 & N/A \\
\hline$\alpha_{4}$ & 0.8 & $\begin{array}{l}2.21 \times \\
10^{-6}\end{array}$ & 0.61 & $\begin{array}{l}1.70 x \\
10^{-6}\end{array}$ & 0.8 & N/A & 0.61 & N/A \\
\hline
\end{tabular}
the numerical values for $\beta_{1}, \beta_{2}, \beta_{3}$ and $\beta_{4}$ may be calculated. If $[\mathrm{C}]$ is the total concentration of copper, then

$$
[\mathrm{C}]=\left[\mathrm{Cu}^{2+}\right]+\left[\mathrm{CuCl}^{+}\right]+\left[\mathrm{CuCl}_{2}\right]+\left[\mathrm{CuCl}_{3}^{-}\right]+\left[\mathrm{CuCl}_{4}^{2-}\right]
$$

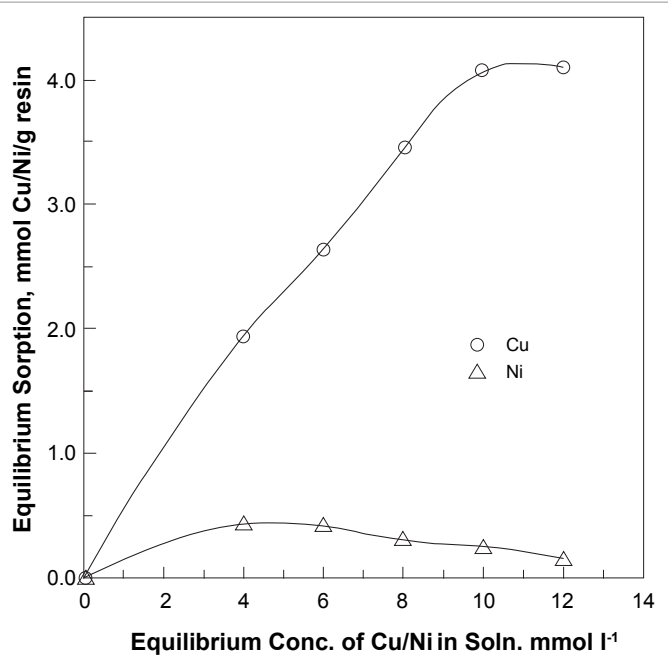

Figure 6: Equilibrium sorption of $\mathrm{Cu}^{2+} / \mathrm{Ni}^{2+}$ from sulphate solution in $1.0 \mathrm{M}$ $\mathrm{NaCl}$ solution on CCPAA resin (resin loading: $1.5 \mathrm{~g} / \mathrm{L}$ ).

\begin{tabular}{|l|l|l|l|l|l|l|}
\hline \multirow{2}{*}{ Fraction } & \multicolumn{2}{|l|}{ Copper } & Nickel & \multicolumn{3}{l|}{ Cobalt } \\
\cline { 2 - 7 } & {$[\mathrm{Cl}] 1.0 \mathrm{M}$} & {$[\mathrm{Cl}] 0.5 \mathrm{M}$} & {$[\mathrm{Cl}] 1.0 \mathrm{M}$} & {$[\mathrm{Cl}] 0.5 \mathrm{M}$} & {$[\mathrm{Cl}] 1.0 \mathrm{M}$} & {$[\mathrm{Cl}] 0.5 \mathrm{M}$} \\
\hline$\alpha_{0}$ & $1.92 \times 10^{-6}$ & $2.36 \times 10^{-5}$ & 0.206 & 0.56 & 0.455 & 0.68 \\
\hline$\alpha_{1}$ & $1.21 \times 10^{-3}$ & $7.45 \times 10^{-3}$ & 0.153 & 0.21 & 0.314 & 0.23 \\
\hline$\alpha_{2}$ & $4.80 \times 10^{-2}$ & $1.48 \times 10^{-1}$ & 0.161 & 0.11 & 0.232 & 0.087 \\
\hline$\alpha_{3}$ & 0.15 & 0.23 & 0.243 & 0.083 & & \\
\hline$\alpha_{4}$ & 0.80 & 0.61 & 0.237 & 0.04 & & \\
\hline
\end{tabular}

Table 2: The fraction of metal ions presented as each species.

Table 3: The fraction of metal ions presented in the mixture of metal ion system.

Substitution in terms of the formation constants, listed in equation 5 , it gives

$$
[\mathrm{C}]=\left[\mathrm{Cu}^{2+}\right]\left(1+\beta_{1}\left[\mathrm{Cl}^{-}\right]+\beta_{2}\left[\mathrm{Cl}^{-}\right]^{2}+\beta_{3}\left[\mathrm{Cl}^{-}\right]^{3}+\beta_{4}\left[\mathrm{Cl}^{-}\right]^{4}\right)
$$

The fraction of $\mathrm{Cu}(\alpha)$ presented as each species may be calculated as a function of $\left[\mathrm{Cl}^{-}\right]$alone:

$$
\begin{aligned}
& \alpha_{0}=\left[\mathrm{Cu}^{2+}\right] / \mathrm{C}=\left(1+\beta_{1}\left[\mathrm{Cl}^{-}\right]+\beta_{2}\left[\mathrm{Cl}^{-}\right]^{2}+\beta_{3}\left[\mathrm{Cl}^{-}\right]^{3}+\beta_{4}\left[\mathrm{Cl}^{-}\right]^{4}\right)^{-1} \\
& a_{1}=\left[\mathrm{CuCl}^{+}\right] / \mathrm{C}=\beta_{1}\left[\mathrm{Cl}^{-}\right] \alpha_{0} \\
& \alpha_{2}=\left[\mathrm{CuCl}_{2}\right] / \mathrm{C}=\beta_{2}\left[\mathrm{Cl}^{-}\right]^{2} \alpha_{0} \\
& \alpha_{3}=\left[\mathrm{CuCl}_{3}^{-}\right] / \mathrm{C}=\beta_{3}\left[\mathrm{Cl}^{-}\right]^{3} \alpha_{0} \\
& \alpha_{4}=\left[\mathrm{CuCl}_{4}^{2-}\right] / \mathrm{C}=\beta_{4}\left[\mathrm{Cl}^{-}\right]^{4} \alpha_{0}
\end{aligned}
$$

By substituting of $\beta$ values and concentrations of $1.0 \mathrm{M}$ and 0.5 $\mathrm{M}\left[\mathrm{Cl}^{-}\right]$, respectively, the fractions of $\mathrm{Cu}(\alpha)$ were calculated and summarized in Table 2.

The formation constants for $\beta_{1}, \beta_{2}, \beta_{3}$, and $\beta_{4}$ of $\mathrm{Ni}$ and the formation constants for $\beta_{1}$ and $\beta_{2}$ of cobalt may also be obtained from literature $[10,12,13]$. For the nickel, they were respectively, $0.74,0.78$, 1.18 , and 1.15 . For the $\mathrm{Co}$, they were 0.69 and 0.51 . The same procedure discussed above was used to calculate the fractions of $\mathrm{Ni}(\alpha)$ and $\mathrm{Co}(\alpha)$. The results were summarized in Table 2.

In the presence of $\mathrm{Cu}^{2+}$ and $\mathrm{Ni}^{2+}$ in mixed system, the total metal concentration was defined as follows:

$$
\begin{aligned}
& {[\mathrm{C}]=\left\{\left[\mathrm{Cu}^{2+}\right]\left(1+\beta_{1, \mathrm{Cu}}\left[\mathrm{Cl}^{-}\right]+\beta_{2, \mathrm{Cu}}\left[\mathrm{Cl}^{-}\right]^{2}+\beta_{3, \mathrm{Cu}}\left[\mathrm{Cl}^{-}\right]^{3}+\beta_{4, \mathrm{Cu}}\left[\mathrm{Cl}^{-}\right]^{4}\right)\right\}} \\
& +\left\{\left[\mathrm{Ni}^{2+}\right]\left(1+\beta_{1, \mathrm{Ni}}\left[\mathrm{Cl}^{-}\right]+\beta_{2, \mathrm{Ni}}\left[\mathrm{Cl}^{-}\right]^{2}+\beta_{3, \mathrm{Ni}}\left[\mathrm{Cl}^{-}\right]^{3}+\beta_{4, \mathrm{Ni}}\left[\mathrm{Cl}^{-}\right]^{4}\right)\right\}
\end{aligned}
$$

when concentrations of $\mathrm{Cl}^{-}, \mathrm{Cu}^{2+}$ and $\mathrm{Ni}^{2+}$ are $1.0 \mathrm{M}, 0.01 \mathrm{M}$ and 0.01 $\mathrm{M}$, respectively, the fractions of copper and nickel complexes may be calculated using the same procedure discussed above. The results were summarized in Table 3 . When $\mathrm{Cl}^{-}$was changed to $0.5 \mathrm{M}$, the calculated fractions of copper and nickel complexes in the mixed system were shown in Table 3. The same procedure was used to calculate the fractions of copper and cobalt and results were summarized in Table 3. Because CCPAA resin is a weak acid cation exchange resin, once resin in the protonated form contacted water, a small percentage of 
carboxylic groups were ionized, which was reported in the article [6]. When it reacted with base, $\mathrm{NaOH}$, (the CCPAA resin was neutralized during the preparation), some of the carboxylic groups would be converted to a more highly ionized form (eq. 6).

$$
\mathrm{R}-\mathrm{COOH}+\mathrm{Na}^{+}+\mathrm{OH}^{-} \rightleftharpoons \mathrm{R}-\mathrm{COO} \mathrm{Na}^{+}+\mathrm{H}_{2} \mathrm{O}(6)
$$

Scheme 1 showed the proposed exchanging process of the CCPAA resin with $\mathrm{Cu}^{2+}$.

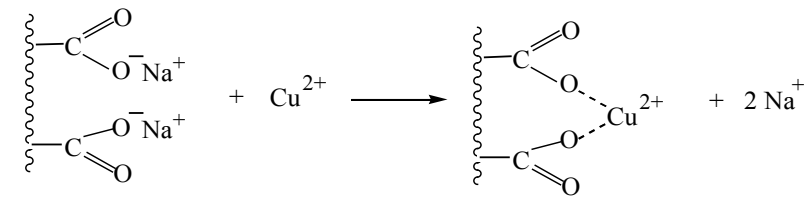

Scheme 1: Ion exchange process of resin with $\mathrm{Cu}^{2+}$ ion.

In contrast, the CCPAA resin reacted with a neutral salt $(\mathrm{NaCl})$ to a very minor degree. This is because one of the products is a highly ionized acid. Therefore $\mathrm{pH}$ value of the solution will be low, and as a result the ionization of the resin will be depressed and driven to the left, as seen from equation 7 .

$$
\mathrm{R}-\mathrm{COOH}+\mathrm{Na}^{+}+\mathrm{Cl}^{-} \rightleftharpoons \mathrm{R}-\mathrm{COO}^{-} \mathrm{Na}^{+}+\mathrm{H}^{+}+\mathrm{Cl}^{-}
$$

Consequently, it only exchanges with $\mathrm{CuCl}^{+}$. Scheme 2 showed the proposed exchange process of the resin with $\mathrm{CuCl}^{+}$.

$$
\left\{\mathrm{C}^{\mathrm{O}}+\mathrm{CuCl}^{+} \longrightarrow \sum_{\mathrm{O}^{-} \mathrm{H}^{+}} \longrightarrow \mathrm{C}_{\mathrm{O}}^{-} \mathrm{O} \cdots \mathrm{CuCl}^{+}+\mathrm{H}^{+}\right.
$$

Scheme 2: Ion exchange process of resin with $\mathrm{CuCl}^{+}$.

By comparison of $\alpha$ values (corresponding to $\mathrm{CuCl}^{+}, \mathrm{CoCl}^{+}$, and $\mathrm{NiCl}^{+}$species, respectively) from Table 3 , it was clear that $\alpha_{1}$ values for $\mathrm{CuCl}^{+}$are much larger than those for $\mathrm{CoCl}^{+}$and $\mathrm{NiCl}^{+}$at $0.5 \mathrm{M}$ and 1.0 $\mathrm{M} \mathrm{NaCl}$ solution. This is one of the possible explanations of separation of $\mathrm{Cu}^{2+}$ from $\mathrm{Co}^{2+}$ and $\mathrm{Ni}^{2+}$. It is well known that other factors such as ionic radius and hydration energies of metal ions also affect selectivity and stability of metal complexes, which were reported by other authors $[14,15]$.

\section{Effect of $\mathrm{pH}$}

The effect of $\mathrm{pH}$ on $\mathrm{Cu}^{2+}, \mathrm{Co}^{2+}$ and $\mathrm{Ni}^{2+}$ sorption by the CCPAA resin was shown in Figure 7. The sorption of these metal ions was relatively unaffected by $\mathrm{pH}$ value above 3 . However, the sorption of metal ions was found to fall drastically at $\mathrm{pH}$ levels below 3 . This is attributed to acidic $\mathrm{pH}$, - $\mathrm{COO}$ groups are protonated preferably and metal uptake is decreased consequently. The results indicated that the sorbed $\mathrm{Cu}^{2+}, \mathrm{Co}^{2+}$ and $\mathrm{Ni}^{2+}$ could be easily stripped by dilute acid.

\section{Sorption rate behavior}

The sorption of $\mathrm{Cu}^{2+}, \mathrm{Co}^{2+}$ and $\mathrm{Ni}^{2+}$ on the CCPAA resin was measured as a function of time at ambient temperature. Taking copper as an example plotted in Figure 8, it can be seen that the rate of sorption on the CCPAA resin was very high for $\mathrm{CuSO}_{4} .80 \%$ of the equilibrium sorption was being attained within 15 minutes from $10 \mathrm{mM}$ solution. However, the rate of sorption on the CCPAA resin was relatively lower for $\mathrm{CoSO}_{4}$ and $\mathrm{NiSO}_{4}$, with only $41.7 \%$ and $58.9 \%$ of the equilibrium sorption being attained within 15 minutes from $10 \mathrm{mM} \mathrm{CoSO}_{4}$ and 8 $\mathrm{mM} \mathrm{NiSO}_{4}$ solution, respectively. The rate of attainment of equilibrium

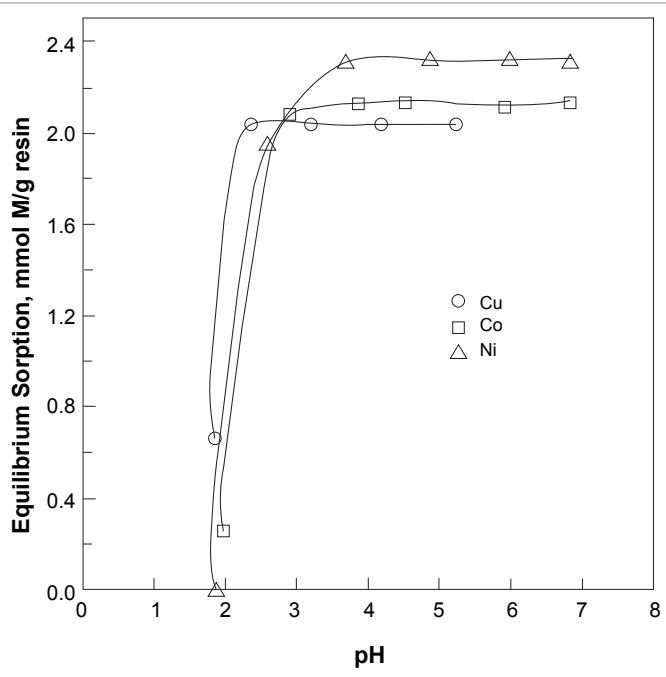

Figure 7: Effect of $\mathrm{pH}$ on equilibrium sorption of $\mathrm{Cu}^{2+}, \mathrm{Co}^{2+}$ and $\mathrm{Ni}^{2+}$ from sulphate solution $(4.0 \mathrm{mM} / \mathrm{L})$ on CCPAA resin (resin loading: $1.5 \mathrm{~g} / \mathrm{L}$ ).

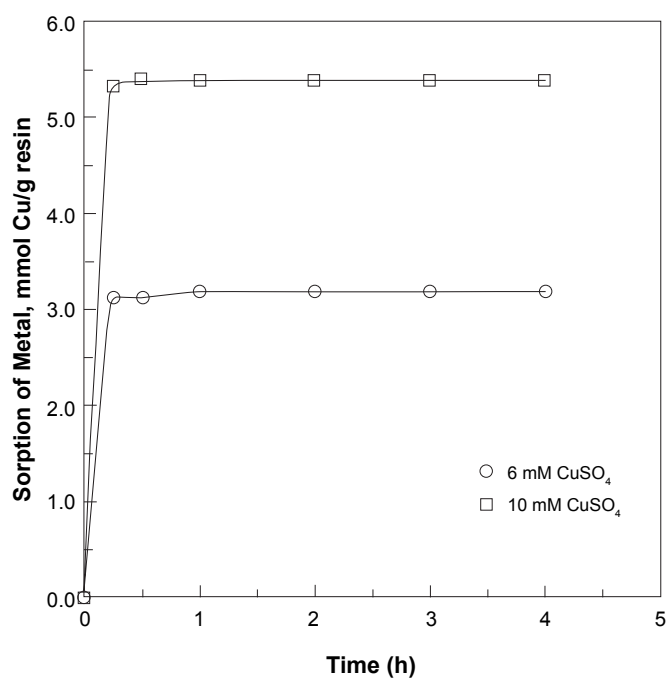

Figure 8: Rate of sorption of $\mathrm{Cu}^{2+}$ from sulphate solution (०) $6.0 \mathrm{mM} / \mathrm{L}$, ( $\square$ ) $10.0 \mathrm{mM} / \mathrm{L}$ ) by CCPAA resin (resin loading: $1.5 \mathrm{~g} / \mathrm{L}$ ).

sorption appeared to be dependent on the solution concentrations of $\mathrm{Cu}^{2+}, \mathrm{Co}^{2+}$ and $\mathrm{Ni}^{2+}$.

\section{Stripping behavior}

Since the metal sorption capacity of the CCPAA resin is very low at lower $\mathrm{pH}$ values, for example, $\mathrm{Ni}^{2+}$ sorption nearly zero at $\mathrm{pH}$ level below 2, therefore, $1.0 \mathrm{~N} \mathrm{HCl}$ was used as a stripping agent. The resin was mixed with the stripping agent at ambient temperature and the solutions were analyzed for $\mathrm{Cu}^{2+}, \mathrm{Co}^{2+}$ and $\mathrm{Ni}^{2+}$, respectively. The stripping characteristics of metal loaded resin were show in Figure 9. Very rapid stripping of sorbed $\mathrm{Cu}^{2+}, \mathrm{Co}^{2+}$ and $\mathrm{Ni}^{2+}$ on the CCPAA resin was obtained. The sorbed $\mathrm{Co}^{2+}$ and $\mathrm{Ni}^{2+}$ sorbed could be stripped completely within 1 hour. However sorbed $\mathrm{Cu}^{2+}$ was stripped to $89 \%$ in 4 hours. This is in accord with the resin showing relatively higher sorption capacity of $\mathrm{Cu}^{2+}$ than $\mathrm{Co}^{2+}$ and $\mathrm{Ni}^{2+}$.

Based on the study results of salt effect, it is assumed that sorbed $\mathrm{Co}^{2+}$ and $\mathrm{Ni}^{2+}$ could be stripped by $\mathrm{NaCl}$ solution. The results showed 


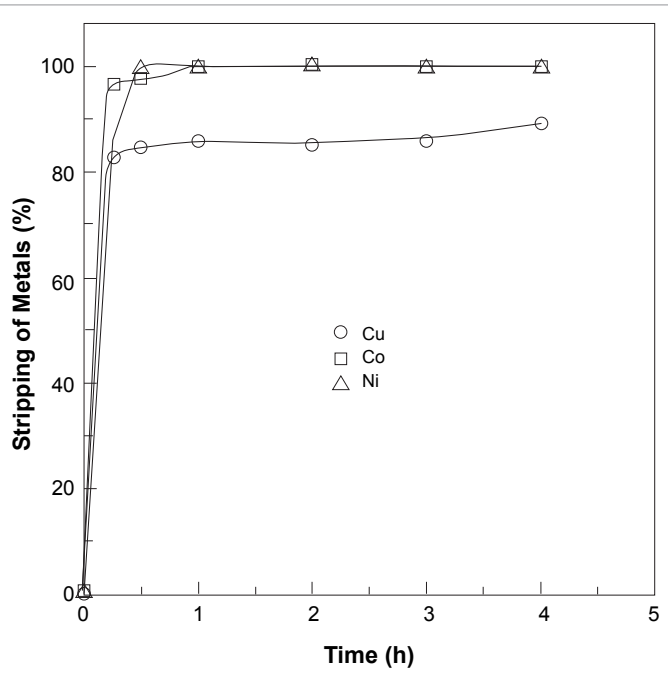

Figure 9: Rates of stripping of CCPAA resin containing metal ions with $1.0 \mathrm{~N}$ $\mathrm{HCl}$ (resin loading: $2 \mathrm{~g} / \mathrm{L}$ ).

that the sorbed $\mathrm{Co}^{2+}$ and $\mathrm{Ni}^{2+}$ could be successfully stripped using 1.0 $\mathrm{M} \mathrm{NaCl}$. However, the stripping rate was relatively low. $85 \%$ of sorbed $\mathrm{Ni}^{2+}$ and $97 \%$ of sorbed $\mathrm{Co}^{2+}$ was stripped in 30 hours.

The CCPAA resin showed high sorption capacity for $\mathrm{Cu}^{2+}, \mathrm{Co}^{2+}$ and $\mathrm{Ni}^{2+}$ ions, but in order to be useful on a commercial scale, the resin would have to be reusable. As mentioned above, sorbed metals on the CCPAA resin could be easily stripped. The recycled CCPAA resin was treated with $0.1 \mathrm{~N}$ sodium hydroxide solutions and used to adsorb $\mathrm{Cu}^{2+}$. The profiles of fresh and reused resin have shown that the first recycling of the resin decayed around 5\%. That means the resin could be reusable, but might have a finite number of regeneration cycles.

\section{Conclusions}

The carboxylic acid group containing CCPAA resin could be used for efficiently removing $\mathrm{Cu}^{2+}, \mathrm{Co}^{2+}$ and $\mathrm{Ni}^{2+}$ from dilute aqueous solutions. This resin with cation exchange capacity, $12.67 \mathrm{meq} / \mathrm{g}$, has $\mathrm{Cu}^{2+}$ sorption capacity, $216 \mathrm{mg} / \mathrm{g}, \mathrm{Co}^{2+}$ sorption capacity, $154 \mathrm{mg} / \mathrm{g}$ and $\mathrm{Ni}^{2+}$ capacity, $180 \mathrm{mg} / \mathrm{g}$, respectively. It was found that $\mathrm{pH}$ affected the equilibrium sorption of the metals on the resin at lower $\mathrm{pH}$ values. The sorption of $\mathrm{Cu}^{2+}, \mathrm{Co}^{2+}$ and $\mathrm{Ni}^{2+}$ ions on the resin fell drastically at $\mathrm{pH}$ levels below 2.3, 2.8 and 3.6, respectively, which indicated the sorbed metals could be stripped by dilute acid. The stripping behaviour of the sorbed metals on the CCPAA resin was studied. It was found that the sorbed $\mathrm{Co}^{2+}$ and $\mathrm{Ni}^{2+}$ could be completely removed by stripping with 1 $\mathrm{N} \mathrm{HCl}$ in 1 hour. The sorbed $\mathrm{Cu}^{2+}$ was stripped to $89 \%$ in 4 hours. This was in accord with the relatively higher absorption strength of $\mathrm{Cu}^{2+}$ than $\mathrm{Co}^{2+}$ and $\mathrm{Ni}^{2+}$. The sorbed $\mathrm{Co}^{2+}$ and $\mathrm{Ni}^{2+}$ were also removed by 1.0 $\mathrm{M} \mathrm{NaCl}$ after a longer time.

After studying the effect of $\mathrm{NaCl}$ on the sorption capacity of the resin, it was found that $\mathrm{NaCl}$ hardly affects $\mathrm{Cu}^{2+}$ sorption on the resin over the whole range of sorbate concentrations employed, whereas the $\mathrm{Co}^{2+}$ and $\mathrm{Ni}^{2+}$ sorption on the resin decreased drastically over the whole range of sorbate concentrations employed. Based on this information, the possibility of separation of $\mathrm{Cu}^{2+}$ from mixture of $\mathrm{Cu}^{2+} / \mathrm{Co}^{2+}$, or from mixture of $\mathrm{Cu}^{2+} / \mathrm{Ni}^{2+}$ in the presence of $\mathrm{NaCl}$ were studied. The results showed that the resin could take 10 times more $\mathrm{Cu}^{2+}$ than $\mathrm{Co}^{2+}$ and $\mathrm{Ni}^{2+}$ at higher metal concentrations $(>8 \mathrm{mM} / \mathrm{L})$. However the sorption capacity difference between $\mathrm{Cu}^{2+}, \mathrm{Co}^{2+}$ and $\mathrm{Ni}^{2+}$ were also rather large at lower metal concentrations $(<6 \mathrm{mM} / \mathrm{L})$. The CCPAA resin could be reusable, but it was noted that the resin had a finite number of regeneration cycles, because of the decrease in sorption capacity of the resin.

\section{References}

1. Huglin MB, Yahya IB, Zakaria MB (1982) Polymer 23: 340-341.

2. Rodehed C, Rånby B (1986) Characterization of sorbed water in saponified start-g-polyacrylonitrile with differential scanning calorimetry. J Appl Polym Sci 32: $3323-3333$

3. Buchholz FL in Buchholz FL and Peppas NA (Eds.) Superabsorbent Polymers, Science and Technology. ACS, Washington DC (1994) ACS Symposium Series 573.

4. Liu ZS, Rempel GL (1997) Preparation of superabsorbent polymers by crosslinking acrylic acid and acrylamide copolymers. J Appl Polym Sci 64: 1345-1353.

5. Maxim S, Flondor A, Bunea I, Luca C, Rabia I, Zerouk J, layadene F, Guettaf $\mathrm{H}$ (1999) Acrylic three-dimensional networks. II. Behavior of different acrylic ion exchangers in the retention and elution processes of some metal cations. $J$ Appl Polym Sci 72: 1387-1394.

6. Liu ZS, Erhan SZ (2002) Conversion of soybean oil into ion exchange resins Removal of copper (II), nickel (II), and cobalt (II) ions from dilute aqueous solution using carboxylate-containing resin. J Appl Polym Sci 84: 2386-2396.

7. Rivas BL, Villegas S (2005) Resins containing amino and carboxylic acid groups. Synthesis, characterization, and metal ion retention properties. J Appl Polym Sci 98: 525-530.

8. Kunin R lon Exchange Resins, Robert, E. Krieger Publishing Co., Huntington, New York, (1972).

9. Chanda M, O'Driscoll KF, Rempel GL (1986) Reactive Polymers. 4: 225-235.

10. Silĺn LG, Martell AE (1964) Stability Constants, Special Publication No. 17, The Chemical Society, Metcafe \& Cooper Limited, London.

11. Riley HL, Smith HC (1934) A Potentiometric Investigation of Electrolytic Dissociation. (Part III Copper Halides). J Chem Soc 1448.

12. Delimarskii YK, Grishchenko VF (1963) Ukr Khim Zh 29: 502

13. Morris DFC, Short EL (1962) Elctrochim Acta 7: 385-391.

14. Atkins PW (1978) Physical Chemistry, Oxford University Press.

15. Tabata M, Suenaga K, Nishimoto J (1994) Effect of 18-Crown-6 on LigandSubstitution and Acid-Dissociation Reactions of Zinc(II)-, Cadmium(II)-, and Lead(II) Porphyrins. Inorg Chem 33: 5503-5508. 